\title{
Comparative Hydrological and Geoelectrical Study on the Quaternary Aquifer in the Deltas of Wadi Badaa and Ghweiba, El Ain El Sukhna Area, Northwest Suez Gulf, Egypt
}

\author{
M. M. El Osta, ${ }^{1}$ A. El. El Sheikh, ${ }^{2}$ and M. S. Barseem ${ }^{3}$ \\ ${ }^{1}$ Geology Department, Faculty of Science, Damanhour University, Damanhour, Bahira 22514, Egypt \\ ${ }^{2}$ Hydrology Department, Desert Research Center, El Matarya 11753, Cairo, Egypt \\ ${ }^{3}$ Geophysical Department, Desert Research Center, El Matarya 11753, Cairo, Egypt
}

Correspondence should be addressed to M. M. El Osta,drmagedelosta@gawab.com

Received 29 May 2010; Accepted 4 October 2010

Academic Editor: Pradeep Talwani

Copyright ( $) 2010$ M. M. El Osta et al. This is an open access article distributed under the Creative Commons Attribution License, which permits unrestricted use, distribution, and reproduction in any medium, provided the original work is properly cited.

\begin{abstract}
El Ain El Sukhna area was selected in the last ten years to initiate many governmental and investmental programs. The different activities in that area depend mainly on the groundwater of the Quaternary aquifer, which forms the main water bearing strata. In the present work, twenty one geoelctrical soundings using the Schlumberger configuration are carried out at selected sites especially in missing parts from wells to delineate the groundwater setting in such sites. Eight of them are conducted in the close vicinity of water wells, where lithologs and pumping test data of these wells are available to relate hydrologic and geoelctric measurements. The pumping tests data are analyzed by using AQTESOLV program and the geolectrical sounding data were interpreted by partial curve matching technique to obtain the initial parameters. The results indicated that, the transmissivity is found to be closely related with transverse resistance and the hydraulic conductivity with average transverse resistivity, while the salinity is inversely related with resistivity. Finally, priority map for drilling water wells is constructed to make the results more illustrative and useful for decision maker. The promising area for drilling is located at the western portion of the study region.
\end{abstract}

\section{Introduction}

The study area $\left(390 \mathrm{~km}^{2}\right)$ lies in the northwestern part of the Gulf of Suez between latitudes $29^{\circ} 38^{\prime}$ and $29^{\circ} 46^{\prime} \mathrm{N}$ and longitudes $32^{\circ} 08^{\prime}$ and $32^{\circ} 22^{\prime} \mathrm{E}$ (Figure 1). It is replenished by local rainfall, which is estimated to be of the order of $20 \mathrm{~mm} / \mathrm{year}$, as an average value of the two neighboring climatic stations, namely, Suez and St. Antony, over a period of about 25 years. Despite the fact that the annual rainfall is considered small, the area may occasionally receive heavy storms that may form considerable source for adequate replenishment, similar to those that took place in 1979 and 1981. In this area, many governmental activities such as the construction of El Sukhna port and many industrial zone as well as tourism projects are now under construction. So, the demand for water resources of appropriate quantity and quality is of vital importance. The development of groundwater resources and the regime of its activity largely depend on the hydraulic parameters of the water-bearing formation and water quality. The present work is carried out in the delta of both Wadi Ghweiba and Badaa in El Ain El Sukhna as an attempt to force investors to follow the complete scientific procedure for exploring the aquifer and defining the suitable sites to drill water wells. The evaluation of water-bearing formation comprises the quantity and quality by using geoelectrical techniques and confirms the results by hydrological studies to delineate:

(1) the sedimentary succession with its vertical and lateral facies changes,

(2) the water bearing formation, its extension, and hydraulic parameters,

(3) the groundwater quality. 


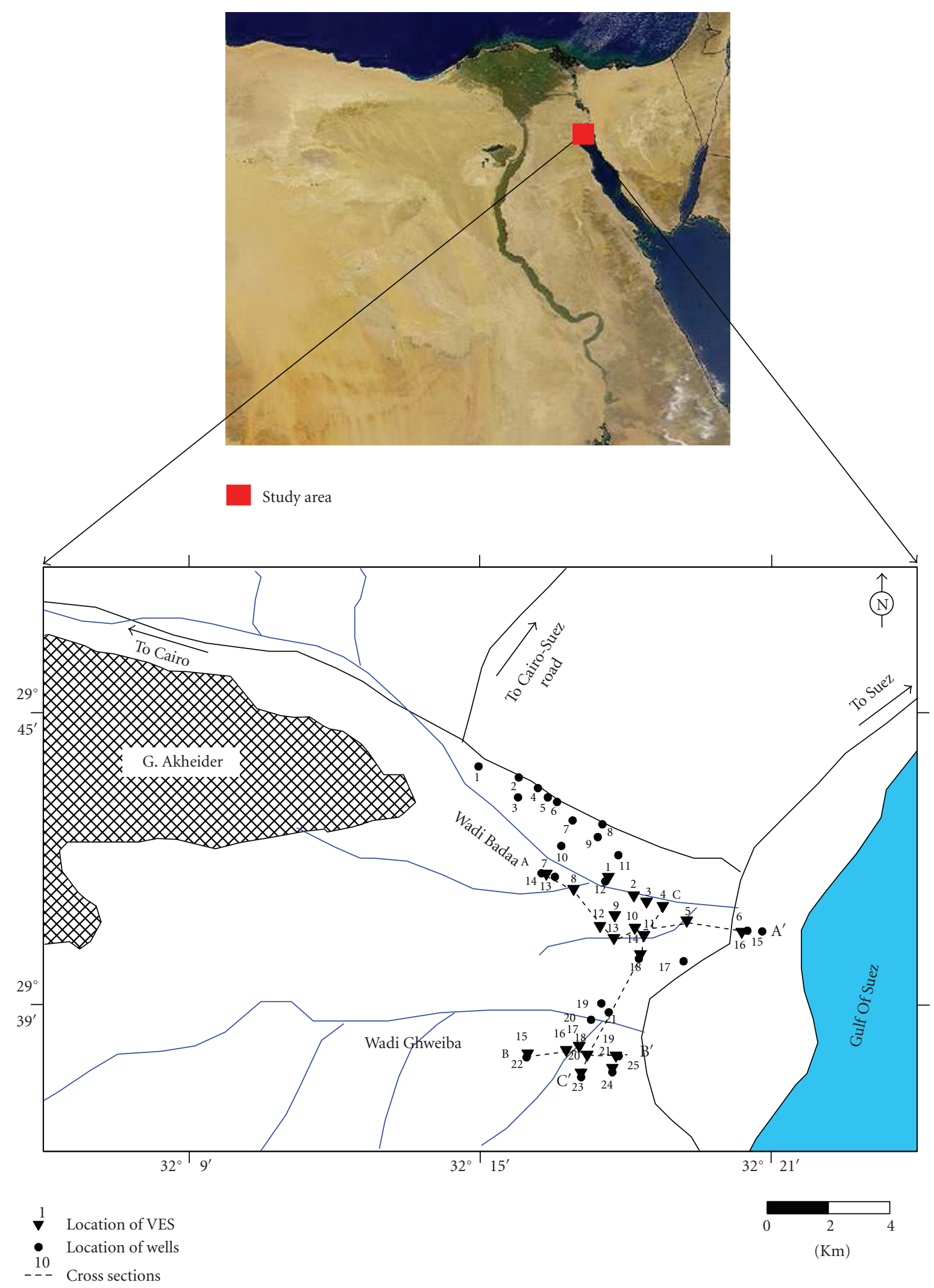

FIGURE 1: Map showing the location of the study area, wells, geoelectrical soundings (VES'es), and directions of cross sections. 


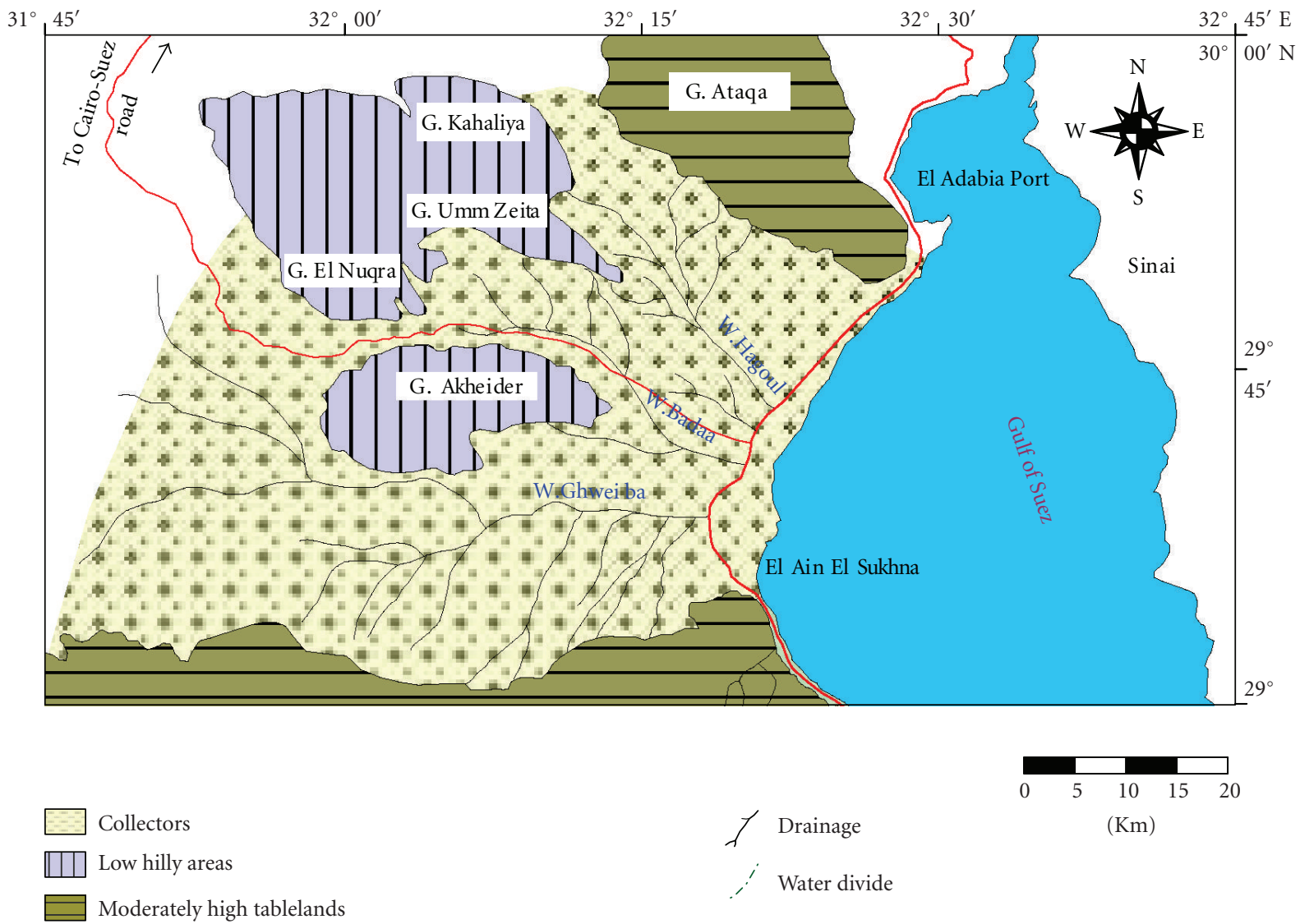

Figure 2: Map showing the main landforms in the study area (modified after Misak [1]).

TABLE 1: Results of hydraulic parameters estimation of the Quaternary aquifer in the deltas of Wadi Badaa and Ghweiba.

\begin{tabular}{lccc}
\hline Well no. & $\begin{array}{c}\text { Saturated } \\
\text { thickness }(\mathrm{m})\end{array}$ & $\begin{array}{c}\text { Transmissivity } \\
T\left(\mathrm{~m}^{2} / \text { day }\right)\end{array}$ & $\begin{array}{c}\text { Hydraulic } \\
\text { Conductivity } K \\
(\mathrm{~m} / \text { day })\end{array}$ \\
\hline 5 & 99.1 & 507.7 & 5.123 \\
6 & 96 & 380.3 & 3.961 \\
12 & 97.5 & 655.59 & 6.724 \\
14 & 99 & 990.25 & 10.00 \\
16 & 94 & 378.07 & 4.022 \\
18 & 99.9 & 755.3 & 7.56 \\
22 & 101.1 & 857.68 & 8.48 \\
23 & 90.6 & 692.99 & 7.64 \\
24 & 79 & 318.528 & 4.032 \\
25 & 78.4 & 698.12 & 8.90 \\
\hline
\end{tabular}

These are attained through the following activities (Figure 1):

(i) inventory of 25 water wells in both Wadis,

(ii) performance of a set of 21 vertical electrical soundings (VES),

(iii) interpretation of obtainable 10 pumping test data.
The different studies for geology, hydrogeology, and geophysics were carried out by a number of authors: Shata [3], Kostandy [4], Said [5, 6], UN [7], Cement Suez Company [8], Arabian Geophysics [9], Mostafa [10], Helal et al. [11], Abd Allatief et al. [12], Aboul Ela [13], El Houseiny [14], and Nasr [15]. Geomorphologically, the area under study represents an elongated depression with a general eastward slope towards the deltas of Wadi Ghawaiba and Badaa (coastal zone). It is bounded from the south and southwest by El Galala El Baharia plateau, from the west by Gebel El Khouder and Gebel El Ramliya and from the north by Gebel El Noqra and Gebel Ataqa (Figure 2). Geologically, the area located to the northwest of the Gulf of Suez is occupied by sedimentary rocks belonging to Quaternary, Pliocene, Miocene Oligocene, Eocene, Cretaceous, Jurassic, and Carboniferous (Figure 3). The Quaternary deposits (alluvial plain and wadi deposits) have a wide distribution in the study area. They are composed of gravels, sands, and shale.

\section{Hydrologic Setting}

The Quaternary sand and gravel deposits form the main water-bearing strata in the Delta of both Wadi Badaa and Ghweiba having generally fresh to brackish water. It is represented by 25 drilled wells to pump water for companies, 


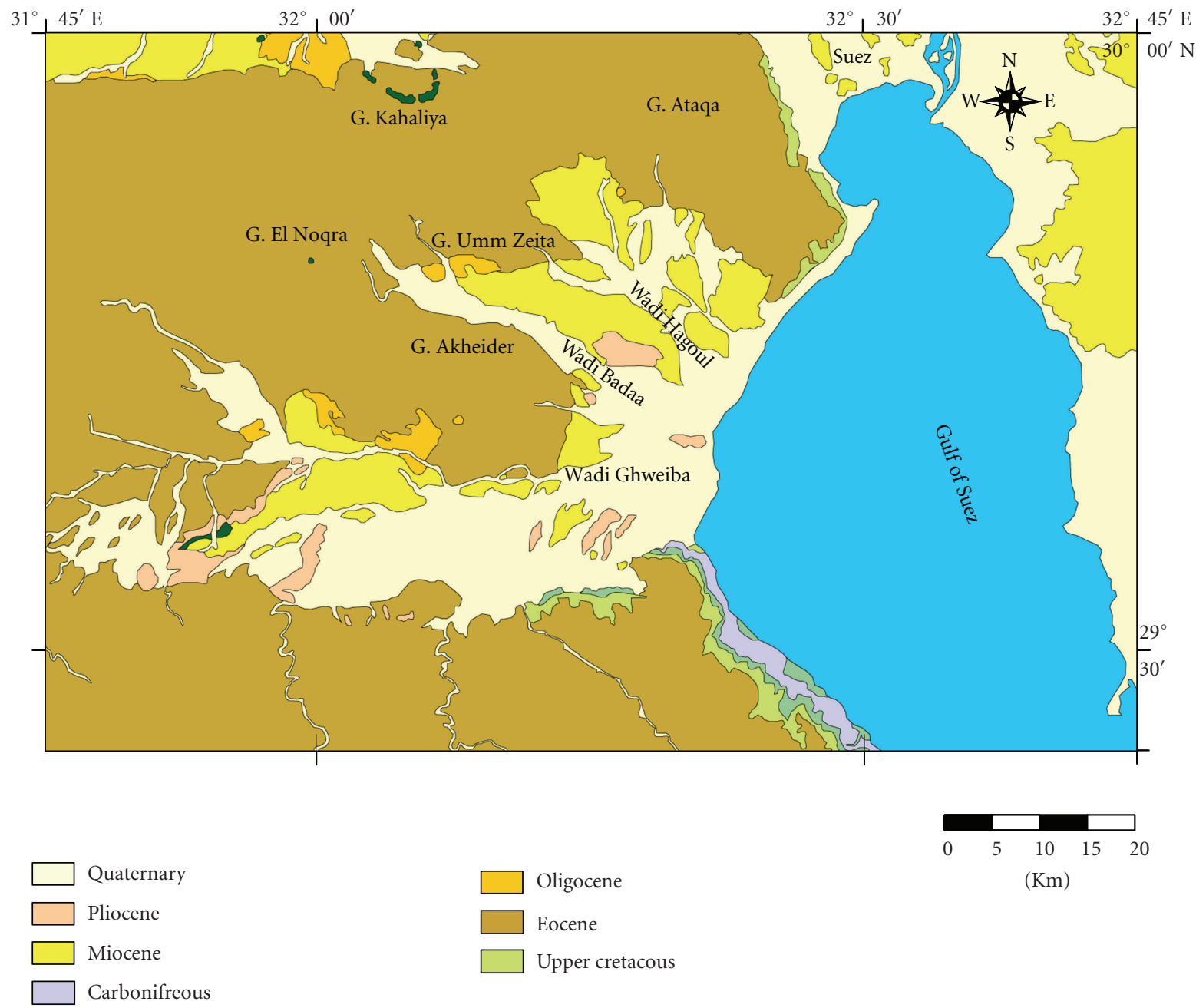

FIGURE 3: Geological map of the study area (Compiled after CONOCO [2]).

TABLE 2: The ranges of the resistivities and the corresponding thicknesses of the geoelectrical layers.

\begin{tabular}{|c|c|c|c|c|c|}
\hline \multirow{2}{*}{ Geoelectrical layer } & \multicolumn{2}{|c|}{ Resistivity range $(\mathrm{Ohm} \cdot \mathrm{m})$} & \multicolumn{2}{|c|}{ Thickness range $(\mathrm{m})$} & \multirow{2}{*}{ Lithological description } \\
\hline & Minimum & Maximum & Minimum & Maximum & \\
\hline A & 140 & 30605 & 0.9 & 3.1 & Surface layer \\
\hline B1 & 27 & 506.5 & 7 & 38.6 & Dry Quaternary deposit (sand and gravels) \\
\hline B2 & 21.02 & 45.8 & 78.4 & 101.7 & Saturated Quaternary zone consist from clayey sand \\
\hline $\mathrm{C} 1$ & 2.8 & 9.7 & 17 & 25.5 & $\begin{array}{ll}\text { clayey sand \& } & \text { Saturated } \\
\text { gravels } & \text { Pliocene-Miocene }\end{array}$ \\
\hline $\mathrm{C} 2$ & 47 & 110.3 & - & - & Limestone \\
\hline
\end{tabular}

factories, and tourism villages distributed in the area. This aquifer is built up of sand and gravel with clay and limestone intercalations. The penetrated thickness of this aquifer reaches about $400 \mathrm{~m}$ at the mouth of Wadi Ghweiba and decreases towards north and northeast [16].

The groundwater of the Quaternary aquifer occurs under free water table condition at depths varying between $9.4 \mathrm{~m}$ in the east and $39.9 \mathrm{~m}$ in the northwest. Its recharge depends mainly on the infiltration of surface runoff water and upward leakage from deep Pliocene and Miocene aquifers (see hydrogeological cross sections), while its discharge occurs either towards the Gulf of Suez or artificial pumping for different purposes (about $3000 \mathrm{~m}^{3} /$ day). The determination of aquifer hydraulic parameters, transmissivity $(T)$, and hydraulic conductivity $(K)$ at constant discharge is done by analysis of pumping test data. These parameters are used to estimate the natural flow of water through the aquifer and its response to abstraction and to predict the aquifer yield and 


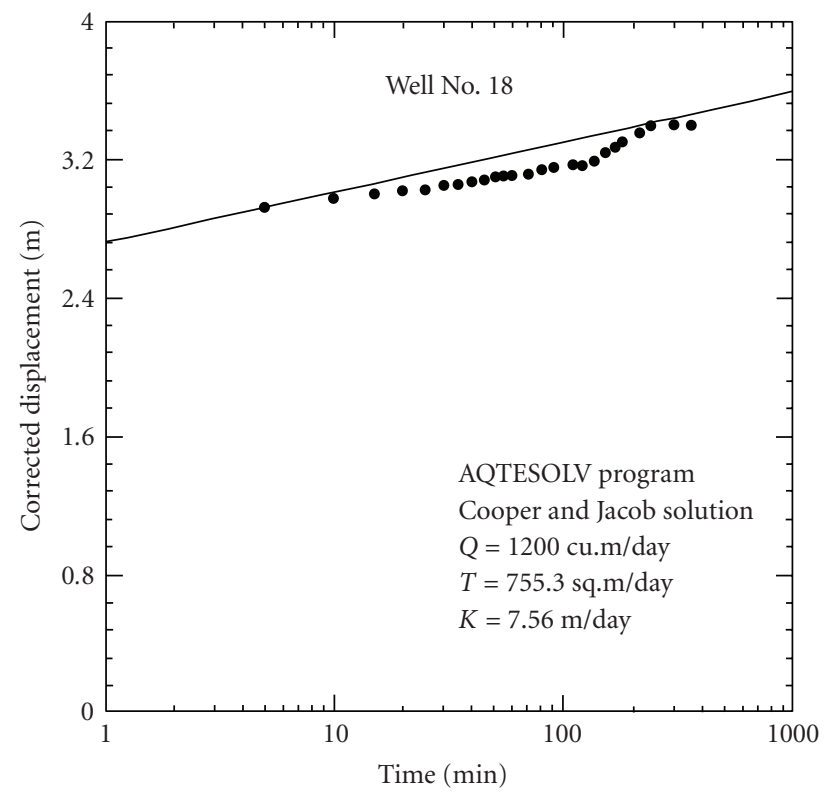

Figure 4: Analysis of data of pumping test for well no. 18 (Wadi Badaa).

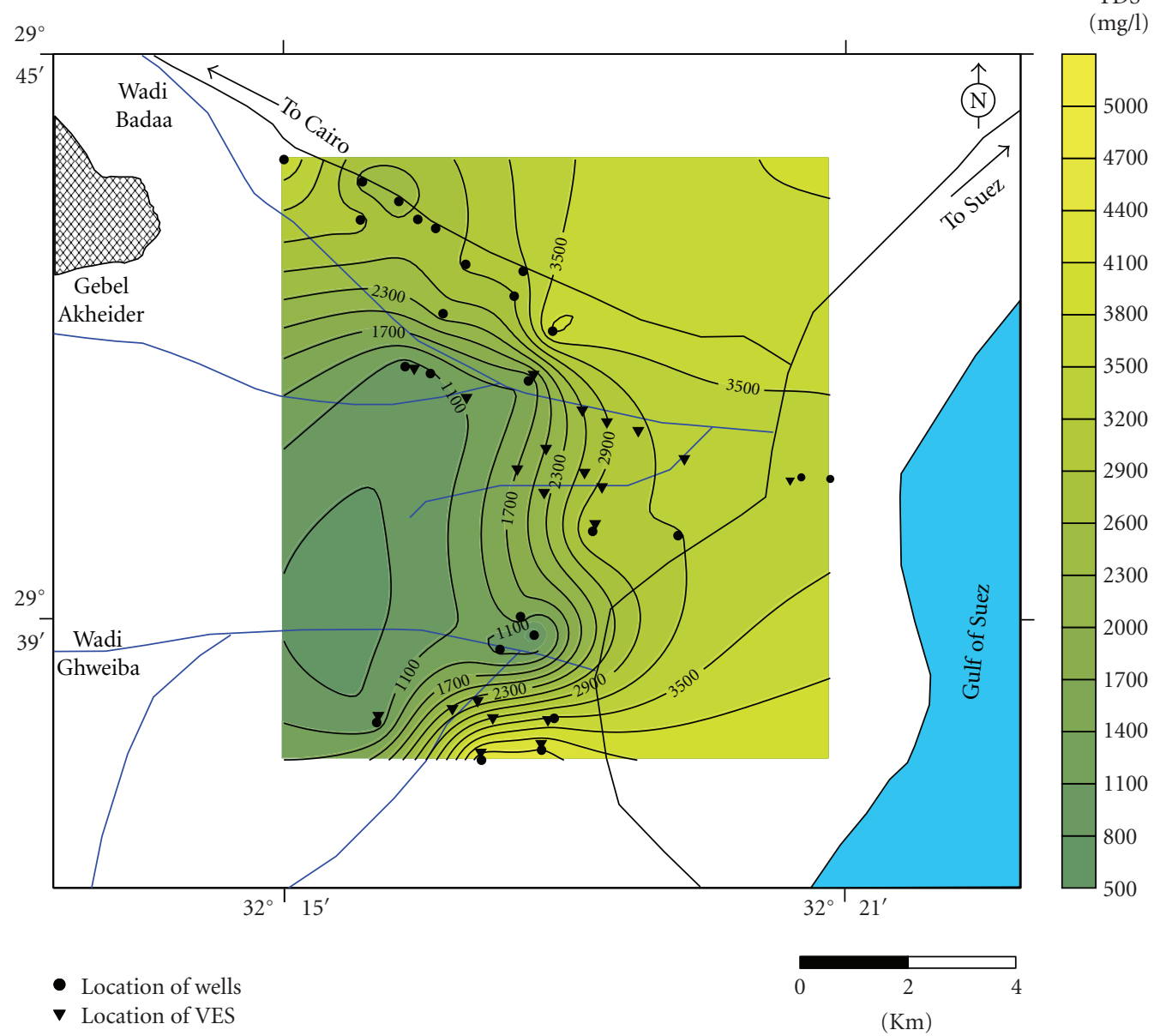

FIGURE 5: Iso-salinity distribution contour map of the deltas of Wadi Badaa and Ghweiba (Augusts, 2009). 


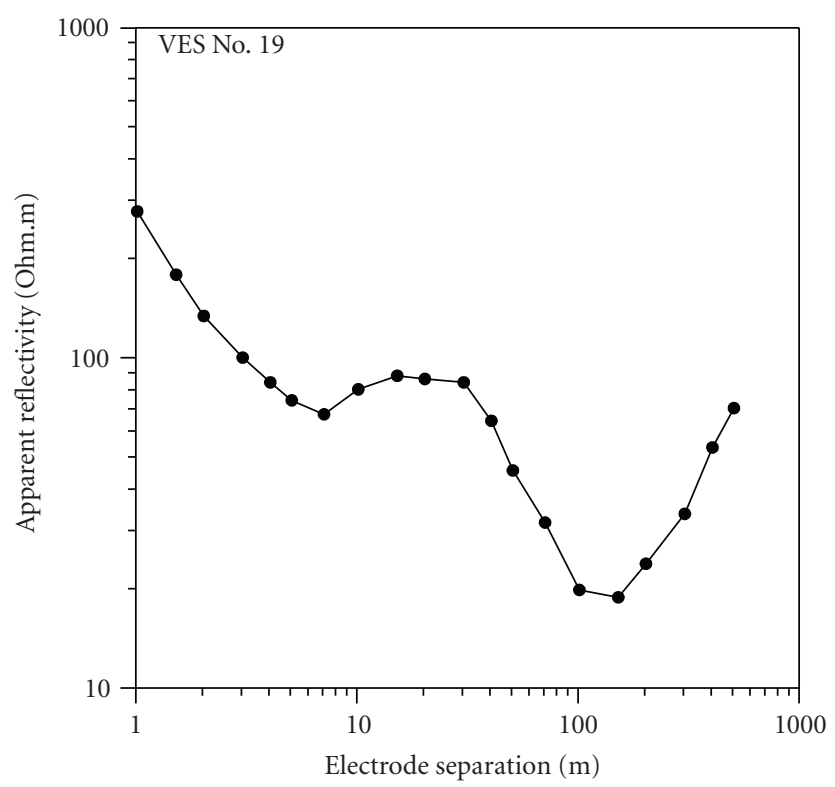

(a)

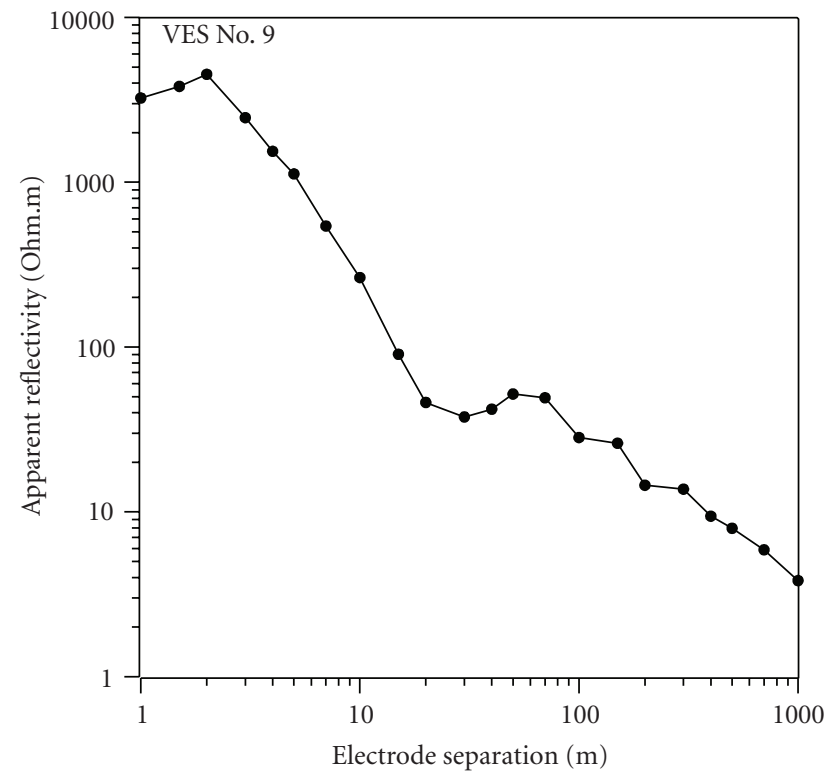

(b)

FIGURE 6: Examples of the resistivity sounding curves.

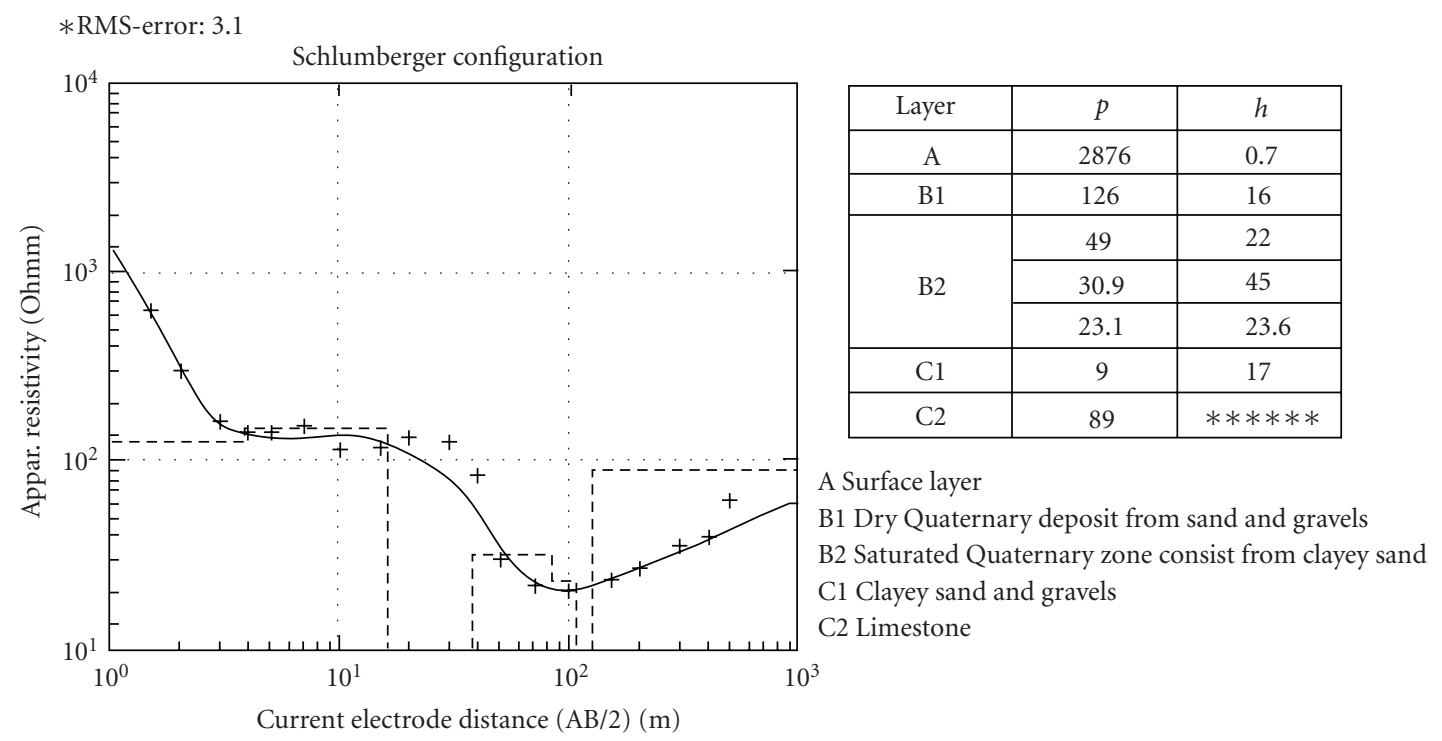

FIgURE 7: Interpretation modeled of VES no. 20.

recharge. This can give preliminary information for further management of groundwater in the area. In the present study, the data of 10 long duration pumping tests are analyzed by using AQTESOLV program Version 4 [17] and by applying the following Cooper and Jacob formula [18]. The results are listed in Table 1

$$
T=2.3 Q / 4 \pi \Delta s, \quad K=\frac{T}{H},
$$

where $T$ is the Transmissivity in $\mathrm{m}^{2} / \mathrm{day}, Q$ is the rate of discharge in $\mathrm{m}^{3} /$ day, $\Delta s$ is the slope in $\mathrm{m}, K$ is the regional hydraulic conductivity in $\mathrm{m} / \mathrm{day}$, and $H$ is the saturated thickness in meter.

The graphical representation of pumping test data is explained by that of well no. 18 as shown in Figure 4 . The obtained parameters from all wells revealed values ranging from $318.528 \mathrm{~m}^{2} /$ day (well no. 24) to $990.25 \mathrm{~m}^{2} /$ day (well no. 14) for transmissivity and from $3.961 \mathrm{~m} /$ day (well no. 6) to $10 \mathrm{~m} /$ day (well no. 14) for hydraulic conductivity. The narrow range of both $T$ and $K$ is mainly attributed to the slight lateral facies changes as well as the similarity of the saturated thickness of the aquifer. 


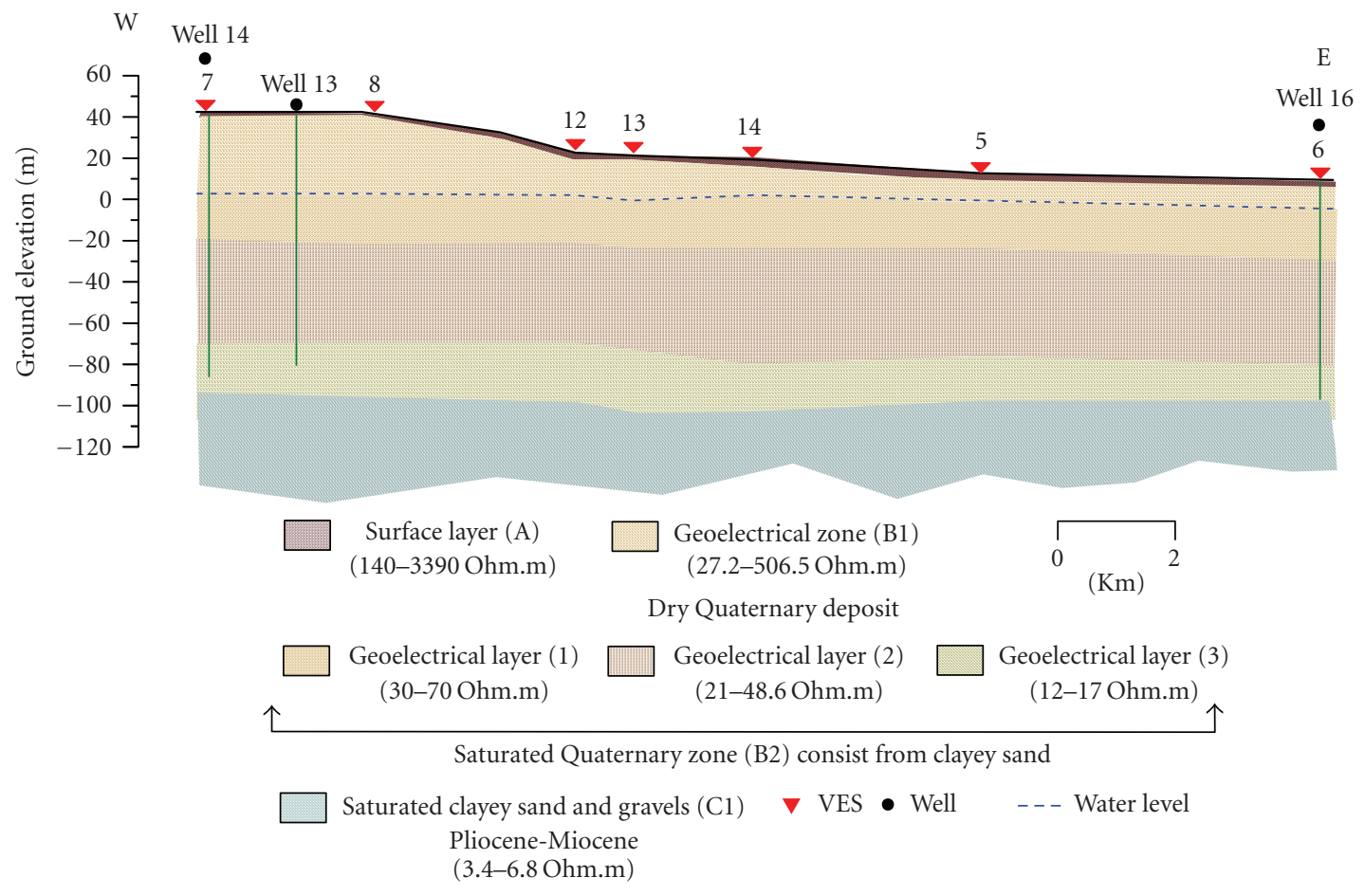

Figure 8: West-East hydrogeological cross section A-A'.

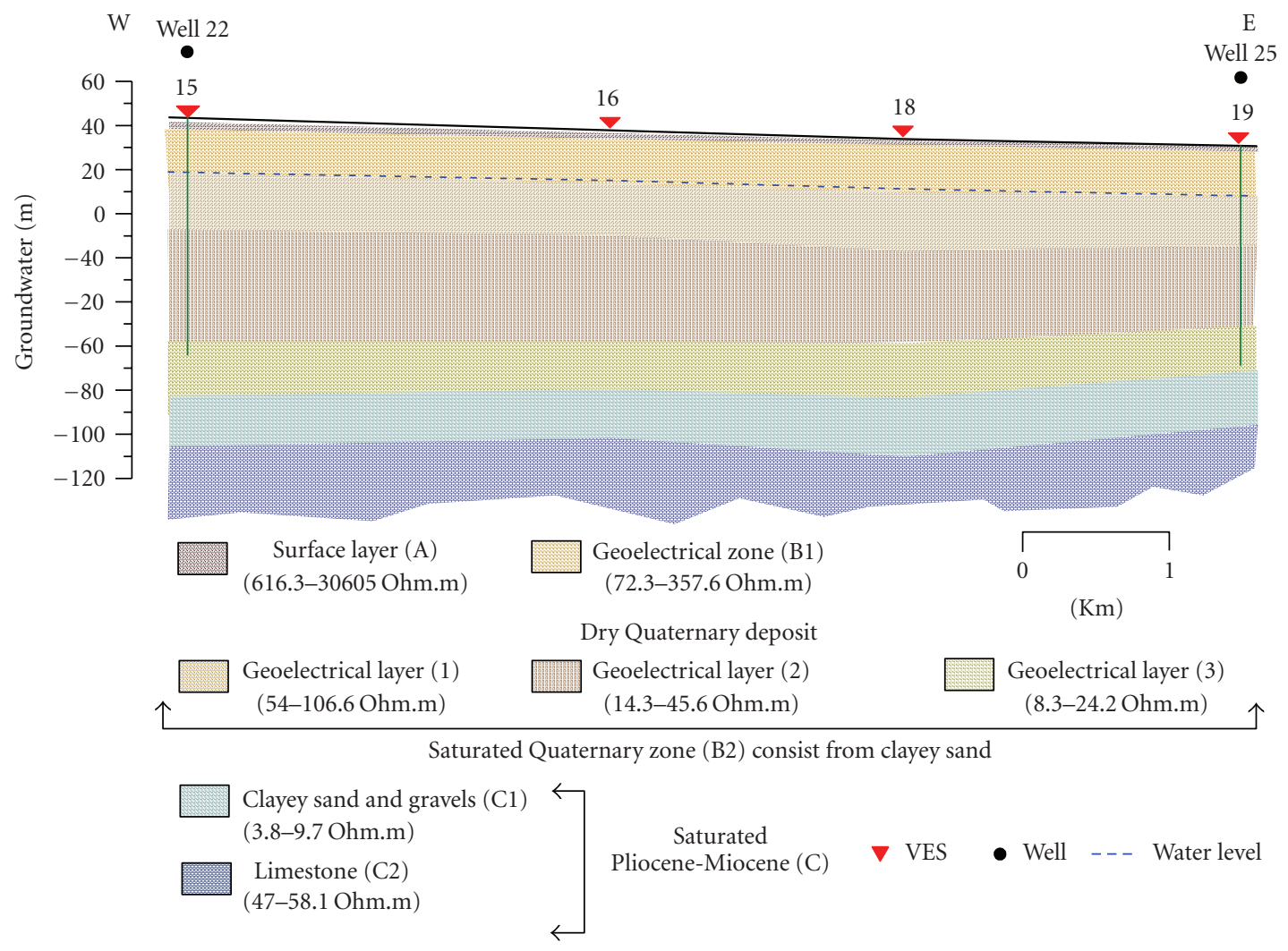

FIgURE 9: West-East hydrogeological cross section B-B' . 


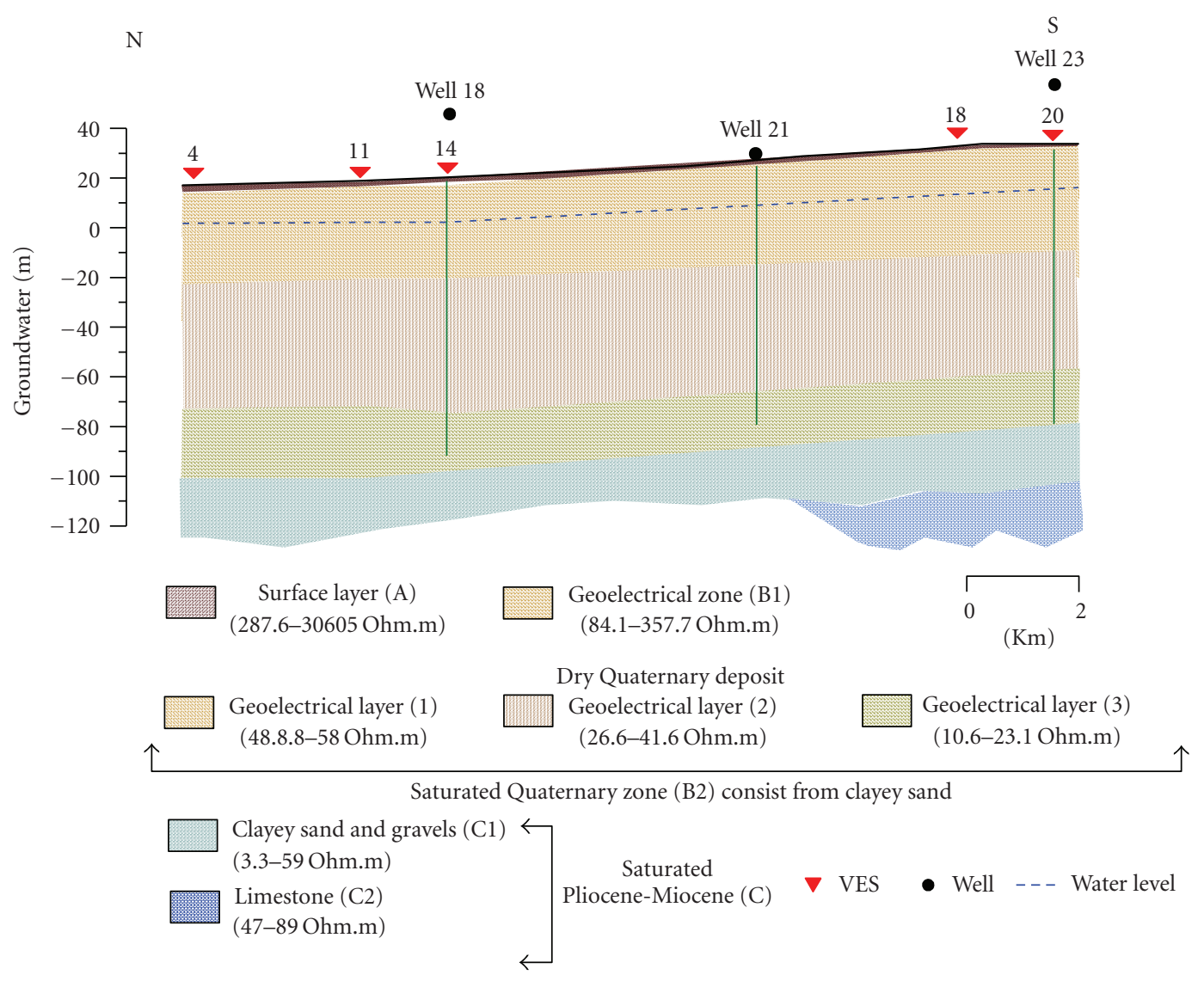

FIGURE 10: North-South hydrogeological cross section C-C'.

\section{Groundwater Quality Assessment}

The salinity measurements of groundwater in the Quaternary aquifer indicate that it belongs to the slightly fresh to brackish water class according to Chebotarev classification [19-21], where the TDS ranges between $560 \mathrm{mg} / \mathrm{l}$ (well no. 21) and $4670 \mathrm{mg} / \mathrm{l}$ (well no. 23). Generally, the higher values of TDS are recorded towards the Gulf of Suez (Figure 5), which indicates more developed stage of chemical composition along the flow path from the upstreams to downstreams of both Wadis. This takes place on account of leaching, dissolution and ion exchange processes. The isotopic investigation carried out by Desouki et al. [16] indicates that the recharge of this aquifer depends mainly on the infiltration of surface runoff and upward leakage from deep aquifers.

\section{Geoelectrical Soundings}

4.1. Sounding Curves. Twenty one vertical electrical sounding were carried out in the investigated area especially in missing parts from wells as in (Figure 1) to delineate the groundwater setting in these localities. Some of the VES stations (nos. 1, 6, 7, 14, 15, 19, 20, and 21) are conducted in the close vicinity of water wells (nos. 12, 16, $14,18,22,25,23$, and 24), respectively, where lithologs and pumping test data of these wells are available. The
Schlumberger electrode configuration was used in VES measurements with maximum electrode separation with a current electrodes separation (AB) starting by 1 meter and ending with 1400 to 2000 meters using terremater SAS 300 and SAS 100 resistivitymeter. The instrument directly measures the resistance with high accuracy. The calculated apparent resistivity is plotted against the corresponding half the electrode separation $(\mathrm{AB} / 2)$ to construct the VES curves (Figure 6). A land topographic surveying was also carried out in order to determine the accurate locations and ground elevations of the sounding station.

4.2. Interpretation of the VES Measurements. The purpose of the VES measurements was to determine the geoelectrical parameters of series subsurface layer. The qualitative and quantitative interpretations of the geoelectrical sounding data are discussed in terms of geoelectrical parameters of resulting layer (resistivities and thicknesses) as follows.

4.2.1. Qualitative Interpretation. The qualitative interpretation includes comparison of the relative changes in the apparent resistivity and thickness of the detected layer on the sounding curves. It gives information about the number of layers, their continuity through the area and reflects the degree of homogeneity or heterogeneity of an individual layer. Figure 6 shows an example of the field 


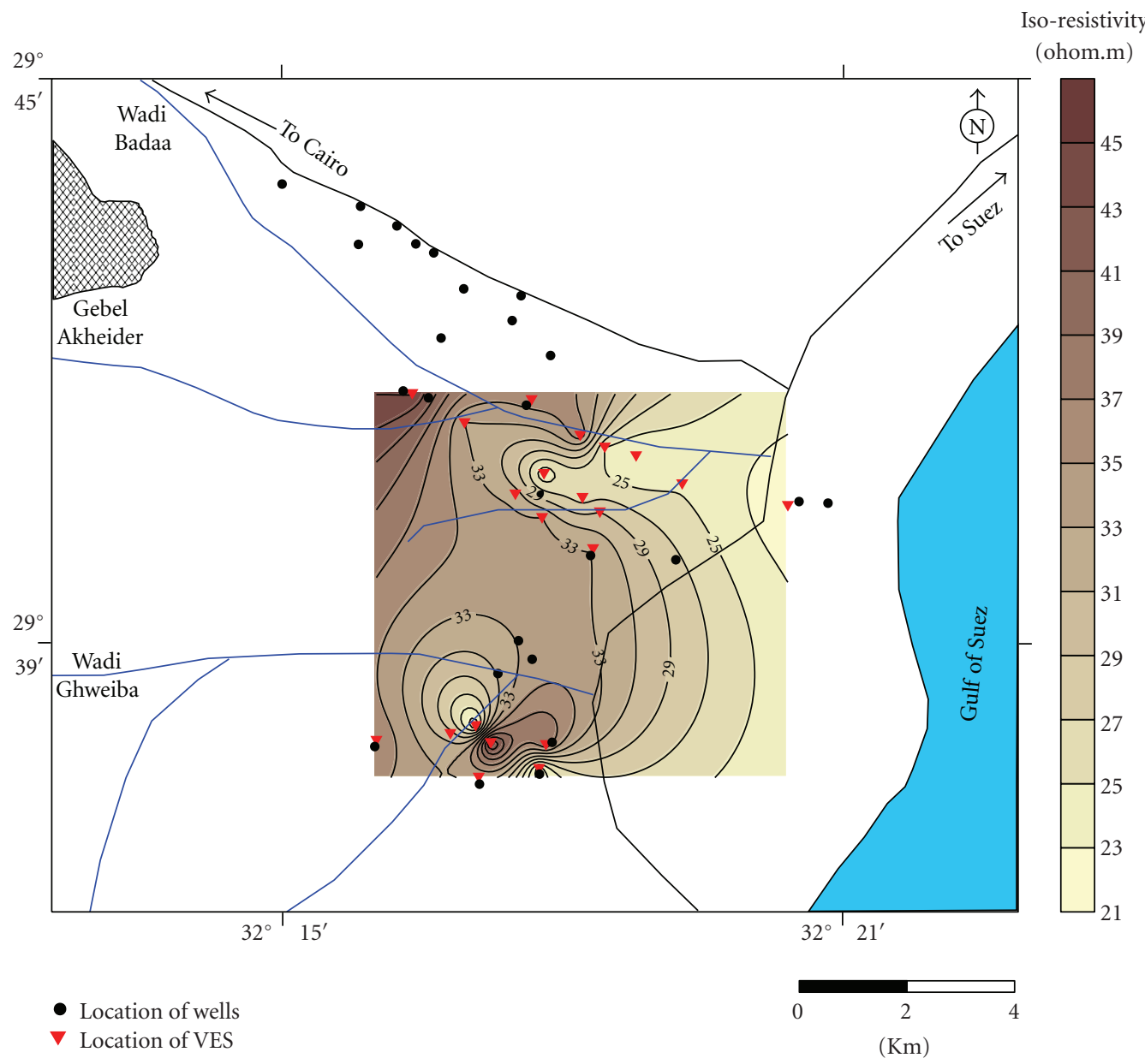

FIgURE 11: Iso-resistivity contour map of the Quaternary aquifer (B2).

representations of the measured VES along the area of study. These soundings are characterized by high resistivity values in the first cycle $(A B=10)$ reflecting a dry zone (gravel and sand), but the differences are clear in the last cycle $(A B>$ 10) reflecting the effect of groundwater on the geophysical parameters (resistivities) as well as the variation in the depths of the layers and their nature. The curves in the delta of Wadi Badda are terminated by Q-type (ended by low resistivity values) which reflects the increase of water salinity. On the other hand, the curves of the delta Wadi Ghweiba are ended by H-type (high resistivity values) reflecting the presence of limestone deposits.

4.2.2. Quantitative Interpretation. The field data of VES has been interpreted quantitatively using the computer program "RESIST" of Van Der Velpen [22] to delineate the subsurface succession of the geoelectrical layers in the area. The initial model has constructed in the view of the lithologic succession of the existed wells. The parameter of the best fit curves, for example, depth, thickness, and resistivity of each layer, are then taken to represent the final interpretation model for the corresponding sounding curves. In order to reach optimum correlation between the geoelectrical layers and the predominant geologic units, some successive geoelectrical layers (mostly the upper most ones) have been grouped together in one layer. The resistivity of such a layer is expressed in terms of the average transverse resistivity $\left(p_{t}\right)$. The true resistivities are related to the geologic information of the existed drilled wells. Figure 7 shows the interpretation of the model resistivity sounding VES no. 20 beside the drilled well no. 23.

4.3. Results and Discussion. The common features characterizing the lithologies and hydrological properties in the investigated area are described in view of constructed hydrogeological cross sections and maps. The comparison between the interpreted data of the VES and the lithology as well as information of some drilled wells revealed that the geoelectrical succession of the area under study consists of three geoelectrical layers, which have been referred to as $\mathrm{A}, \mathrm{B}$ and $\mathrm{C}$. The geoelectrical parameters, resistivities and thicknesses are tabulated in Table 2.

Three hydrogeological cross sections have been constructed based on the interpreted data of the VESs and lithologic data of wells (Figures 8, 9, and 10). These sections illustrate the sedimentary succession, lateral, and vertical 


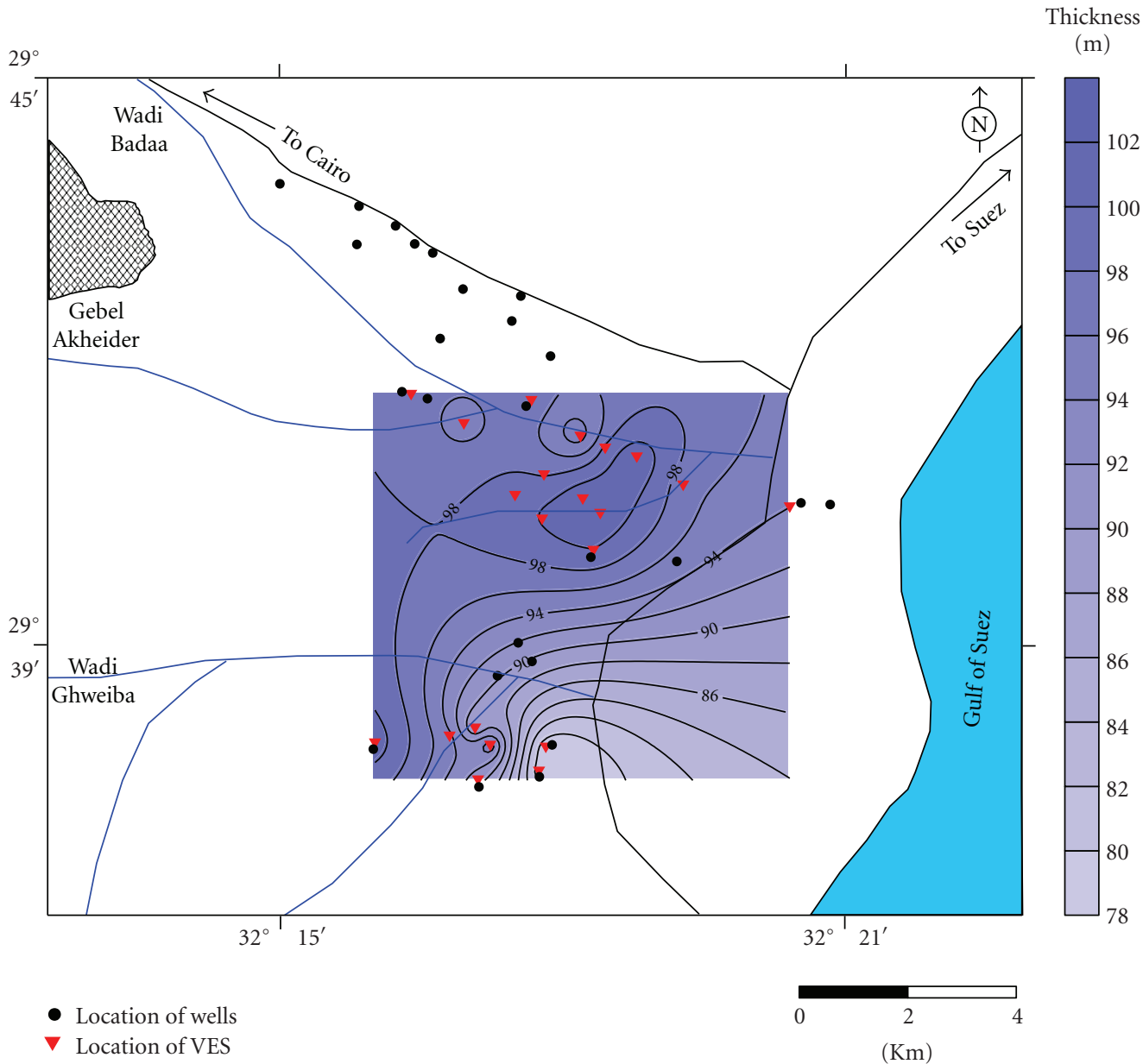

FIgURE 12: Isopach contour map of the Quaternary aquifer (B2).

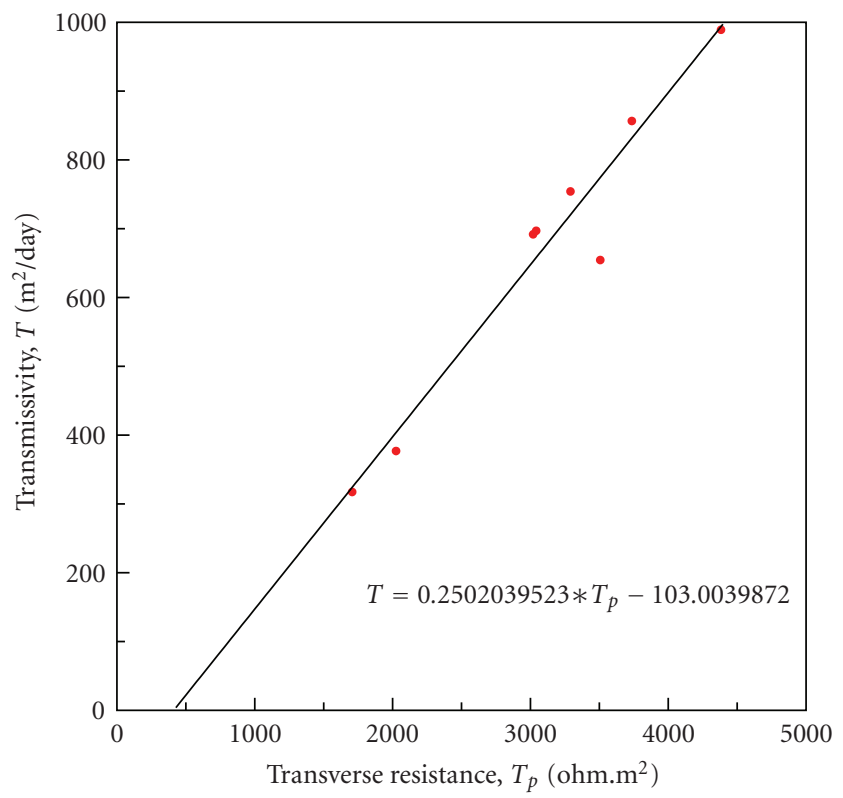

- Data points

FIGURE 13: Relation between transmissivity and transverse resistance. 


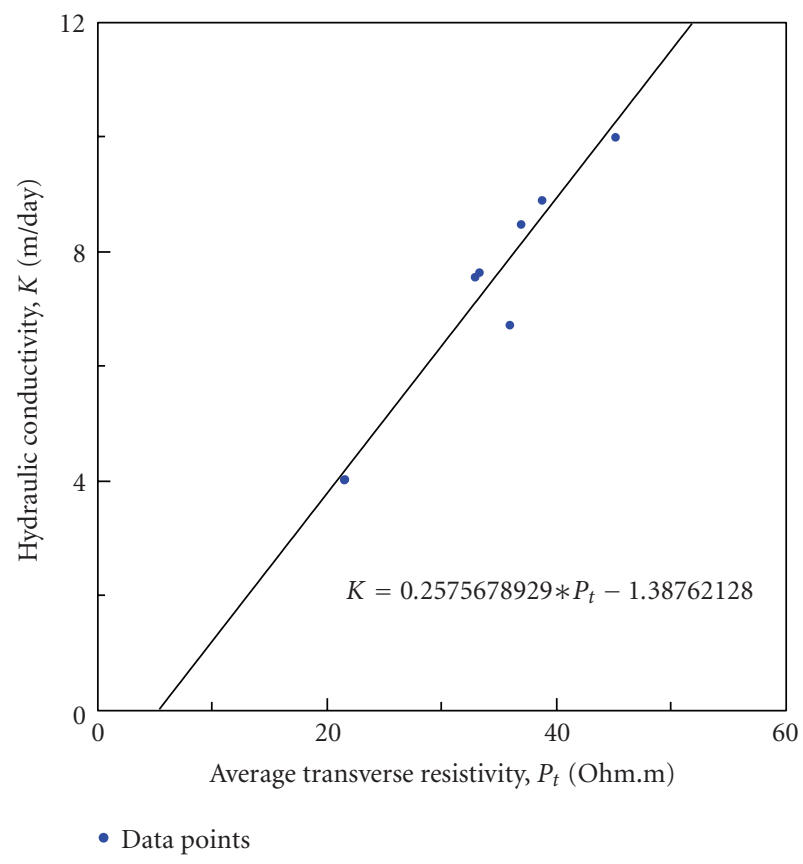

FIGURE 14: Relation between hydraulic conductivity and average transverse resistivity.

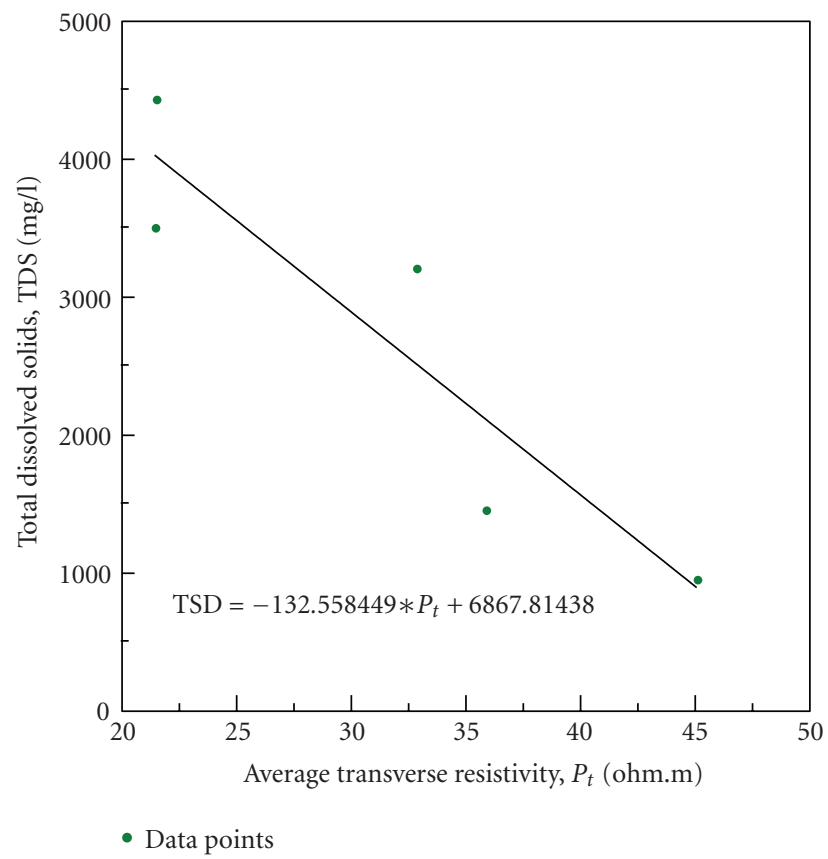

FIGURE 15: Relation between TDS and average transverse resistivity.

resistivity that reflects the lithology changes of the different layers as follows.

(i) The first layer (A) consists of dry sediments such as sand, gravel, and clay belonging to the Quaternary period. This layer shows its maximum resistivity value at VES no. (18) $(30605 \mathrm{Ohm} \cdot \mathrm{m}$.) whereas its minimum resistivity is recorded at VES no. (6)
$(140 \mathrm{Ohm} \cdot \mathrm{m})$. This layer exhibits a thickness which does not exceed $3 \mathrm{~m}$.

(ii) The second layer (B) consists of calcareous and clayey sand, gravel, and shale related to Quaternary, according to the lithology and well information at VES no. (20). It can be divided into an upper part (B1) and a lower are (B2). The upper (B1) 


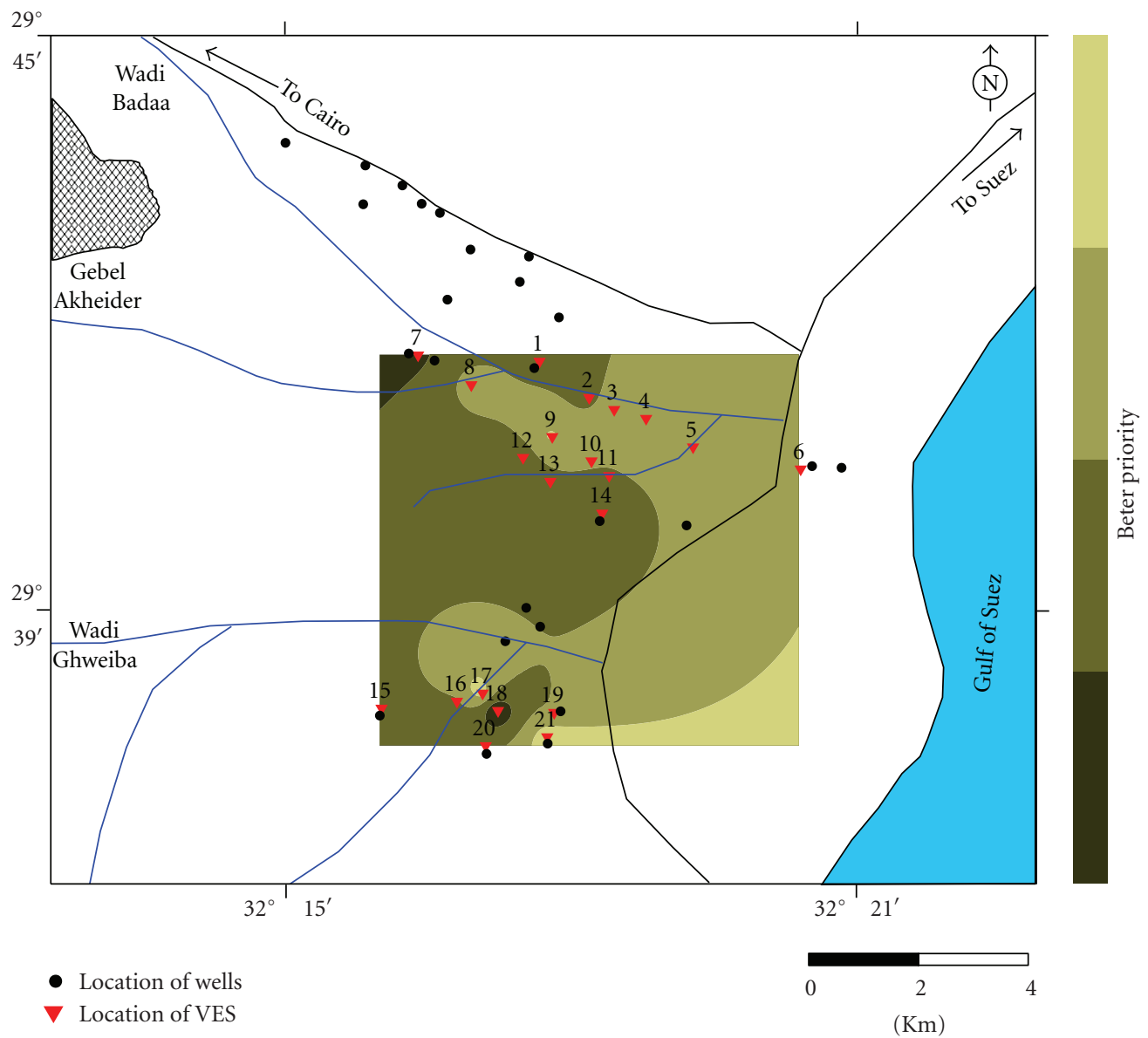

FIGURE 16: Priority map for drilling water wells in the study area.

is dry and its resistivity ranges between $27 \mathrm{Ohm} \cdot \mathrm{m}$ at VES no. (5) and $506.5 \mathrm{Ohm} \cdot \mathrm{m}$ at VES no. (7). The thickness of this part ranges between $7 \mathrm{~m}$ at VES no. (5) and $38.6 \mathrm{~m}$ at VES no. (8). The lower part (B2) is saturated with water and it consists of from three geoelectrical layers according to the lithologic information of wells. These three layers can be gathered in one zone and expressed in terms of an average transverse resistivity $\left(p_{t}\right)$. It shows resistivity ranges from $21.05 \mathrm{Ohm} \cdot \mathrm{m}$ at VES no. (17) to $45.8 \mathrm{Ohm} \cdot \mathrm{m}$ at VES no. (18). This part reaches its minimum thickness $(78.4 \mathrm{~m})$ at VES no. (19) and well no. (25) while its maximum thickness $(101.7 \mathrm{~m}$.) at VES no. (10).

(iii) The last detected layer $(\mathrm{C})$ is saturated and divided into two parts (C1) and (C2) belonging to PlioceneMiocene ages. The upper part (C1) is composed from clayey sand and gravel. Its resistivity value ranges from $2.8 \mathrm{Ohm} \cdot \mathrm{m}$ at VES no. (1) to $9.7 \mathrm{Ohm} \cdot \mathrm{m}$ at VES no. (15). The thickness of this part varies from $17 \mathrm{~m}$ at VES no. (20) to $25.5 \mathrm{~m}$ at VES no. (15). The lower part (C2) is detected at some sound. This layer corresponds to saturated limestone and shows resistivity varies from $47 \mathrm{Ohm} \cdot \mathrm{m}$ at VES no. (5) to $110 \mathrm{Ohm} \cdot \mathrm{m}$ at VES no. (17).

According to the geoelectrical results and lithologic information of drilled wells, the Quaternary aquifer represents the major promising aquifer in the study area. It consists of calcareous and clayey sand, gravel, and shale acting as first water bearing zone. On the other hand, the PlioceneMiocene aquifer is divided into two parts (C1 \& C2). The upper one corresponds to clayey sand and gravel, and the lower one is represented by limestone. The iso-resistivity contour map of the Quaternary aquifer (Figure 11) shows a general decrease in resistivity value eastward direction (Gulf of Suez), which indicates poor water quality (high salinity and or high clay content). Also, the spatial distribution of the thickness for this aquifer is illustrated in (Figure 12). This map shows gradual decrease in thickness from northwest to east and southeastern direction.

4.4. Predicted Hydraulic Parameters of the Quaternary Aquifer. The estimation of aquifer characteristics can be offered by surface geoelectrical measurements. This approach is based on the fact that the electric current follows the path of least resistance, as water does within and around the rock pores. The mode of conduction of electrcity is ionic and the 
TABLE 3: Geoelectrical parameters and predicted transmissivity, hydraulic conductivity, and salinity of the Quaternary aquifer from the Vertical Electrical Soundings (VESs).

\begin{tabular}{|c|c|c|c|c|c|c|c|c|c|}
\hline VES no. & $\begin{array}{c}\text { Ground } \\
\text { elevat. } \\
( \pm \mathrm{m})\end{array}$ & $\begin{array}{c}\text { Depth to } \\
\text { water }(\mathrm{m})\end{array}$ & $\begin{array}{l}\text { Water table } \\
\qquad(\mathrm{m})\end{array}$ & $\begin{array}{l}\text { Saturated } \\
\text { thickness } \\
(\mathrm{m})\end{array}$ & $\begin{array}{c}T_{p} \\
\left(\mathrm{Ohm} \cdot \mathrm{m}^{2}\right)\end{array}$ & $\begin{array}{c}P_{t} \\
(\mathrm{Ohm} \cdot \mathrm{m})\end{array}$ & $\begin{array}{c}\text { Predicted } T \\
\left(\mathrm{~m}^{2} / \text { day }\right)\end{array}$ & $\begin{array}{l}\text { Predicted } K \\
\quad(\mathrm{~m} / \text { day })\end{array}$ & $\begin{array}{c}\text { Predicted } \\
\text { TDS (mg/l) }\end{array}$ \\
\hline$* 1$ & 27 & 24.8 & 2.2 & 97.5 & 3501 & 35.91 & 772.959 & 7.861 & 2107.64 \\
\hline 2 & 22 & 20 & 2 & 92.5 & 3365.4 & 36.38 & 739.032 & 7.982 & 2045.33 \\
\hline 3 & 19 & 18 & 1 & 98.5 & 2451.2 & 24.89 & 510.295 & 5.023 & 3568.43 \\
\hline 4 & 17 & 15.5 & 1.5 & 101.5 & 2344.56 & 23.10 & 483.614 & 4.562 & 3805.71 \\
\hline 5 & 22 & 9.4 & 12.6 & 96.8 & 2400.8 & 24.80 & 497.685 & 5.00 & 3580.36 \\
\hline$* 6$ & 10 & 13.3 & -3.3 & 94 & 2019 & 21.48 & 402.157 & 4.144 & 4020.45 \\
\hline$* 7$ & 42 & 38.5 & 3.5 & 97 & 4377 & 45.12 & 992.138 & 10.233 & 886.77 \\
\hline 8 & 43 & 39.9 & 3.1 & 95.2 & 3133.8 & 32.92 & 681.085 & 7.091 & 2503.99 \\
\hline 9 & 23 & 20.1 & 2.9 & 97.9 & 2282.12 & 23.31 & 467.991 & 4.616 & 3777.87 \\
\hline 10 & 20 & 17.5 & 2.5 & 101.7 & 2649.17 & 26.05 & 559.828 & 5.322 & 3414.66 \\
\hline 11 & 21 & 17 & 4 & 101.4 & 2948.6 & 29.08 & 634.747 & 6.102 & 3013.01 \\
\hline 12 & 23 & 19.9 & 3.1 & 99.5 & 3190.12 & 32.06 & 695.176 & 6.87 & 2546.40 \\
\hline 13 & 21 & 20.7 & 1.3 & 100.1 & 3312.79 & 33.09 & 725.868 & 7.135 & 2481.45 \\
\hline * 14 & 21 & 19 & 2 & 99.9 & 3284.61 & 32.88 & 718.818 & 7.081 & 2509.29 \\
\hline$* 15$ & 42 & 23.3 & 18.7 & 101.1 & 3729.85 & 36.89 & 830.219 & 8.114 & 1977.73 \\
\hline 16 & 37 & 22.8 & 14.2 & 94.6 & 2831.62 & 29.93 & 605.478 & 6.321 & 2900.34 \\
\hline 17 & 35 & 18.6 & 16.4 & 88 & 1850 & 21.02 & 359.873 & 4.026 & 4081.43 \\
\hline 18 & 34 & 22 & 12 & 95.4 & 4364.6 & 45.75 & 989.036 & 10.396 & 803.26 \\
\hline$* 19$ & 30 & 22 & 8 & 78.4 & 3036 & 38.72 & 656.615 & 8.585 & 1735.15 \\
\hline$* 20$ & 34 & 16.7 & 17.3 & 90.6 & 3013.66 & 33.26 & 651.025 & 7.179 & 2458.92 \\
\hline$* 21$ & 29 & 15.2 & 13.8 & 79 & 1701 & 21.53 & 322.59 & 4.157 & 4013.8 \\
\hline
\end{tabular}

Where: ${ }^{*}$ is well beside VES, $T_{p}$ is transverse resistance, $P_{t}$ is average transverse resistivity, $T$ is transmissivity, $K$ is hydraulic conductivity, and TDS is total dissolved solids.

TABLE 4: The thickness, TDS, depth to water, transmissivity, and hydraulic conductivity category ranges for the saturated layer (B2).

\begin{tabular}{lccccc}
\hline Category & \multirow{2}{*}{ Thickness ranges $(\mathrm{m})}$. & TDS ranges $(\mathrm{mg} / \mathrm{l})$ & $\begin{array}{c}\text { Depth to water ranges } \\
(\mathrm{m})\end{array}$ & $\begin{array}{c}\text { Transmissivity } T \\
\left(\mathrm{~m}^{2} / \text { day }\right)\end{array}$ & $\begin{array}{c}\text { Hydraulic conductivity } \\
K(\mathrm{~m} . / \text { day })\end{array}$ \\
\hline 1 & $\geq 95$ & $\leq 900$ & $\leq 20$ & $>850$ & $>9$ \\
2 & $>900 \leq 500$ & $>20 \leq 30$ & $>500 \leq 850$ & $>6 \leq 9$ \\
3 & $>905$ & $>3000$ & $>30 \leq 35$ & $>400 \leq 500$ & $>5 \leq 6$ \\
4 & $<80$ & $>3000$ & $<400$ & $<5$ \\
\hline
\end{tabular}

resistivity of the medium controlled by porosity and water conductivity based on the rock matrix. Thus, at the pore level, the electrical path, is similar to the hydraulic path and the resistivity should reflect the hydraulic conductivity. The similarity in the behavior of the electrical path through a medium with the hydraulic path is definitions of the electric and hydraulic parameters. The total transverse unit resistance $\left(T_{\rho}\right)$ is given by

$$
T_{\rho}=\sum h_{i} * p_{i}
$$

where $h_{i}$ and $p_{i}$ are the thickness and resistivity of $i$ th layer in the section, respectively.

Also, the transmissivity $(T)$ is represented by the relation

$$
T=\sum h_{i} * K_{i}
$$

where $h_{i}$ and $K_{i}$ are the thickness and resistivity of $i$ th layer in the section, respectively.

The average transverse resistivity $\left(P_{t}\right)$ is given by

$$
P_{t}=\sum p_{i} * \frac{h_{i}}{\sum h_{i}} .
$$

And the hydraulic conductivity $(K)$ is given by

$$
K=\sum K_{i} * \frac{h_{i}}{\sum h_{i}} .
$$

These model parameters are used to obtain the transmissivities from the corresponding transverse resistance and the hydraulic conductivities from the corresponding average transverse resistivities. According to the interpretation of each sounding curve, the transverse resistance and the 
average transverse resistivity have been calculated and listed in Table 3. Several works, to establish empirical relationships between various aquifer hydraulic parameters obtained both from pumping test analysis and geoelectrical measurement have been carried out by Kelly [23] who establishes an empirical relation between aquifer electrical resistivity $\left(P_{t}\right)$ and hydraulic conductivity $(K)$. Also, Mbonu et al. [24] calculated aquifer hydraulic conductivity and transmissivity from the model obtained from the interpretation of geoelectrical sounding in part of the Umuahia area of Nigeria. In the present work, the following empirical relationships between geoelectrical and hydraulic parameters are constructed.

\subsubsection{Relation between Transmissivity and Transverse Resis-} tance. The relation between transmissivity $(T)$ obtained from pumping test analysis for 8 wells and computed transverse resistance $\left(T_{\rho}\right)$ of the aquifer from vertical electrical soundings beside these wells is shown in Figure 13. This plot confirms the dependance of $T$ with $T_{\rho}$ as $T=$ $0.2502039523 * T_{\rho}-103.0039872$ with coefficient of determination of 0.943868 . Accordingly, the transmissivity is found to be closely related with transverse resistance which is in agreement with the earlier work done by Frohlich and Kelly [25].

4.4.2. Relation between Hydraulic Conductivity and Average Transverse Resistivity. The hydraulic conductivity $(K)$ values have been plotted versus the average transverse resistivity $\left(P_{t}\right)$. These plots and their best fit are shown in Figure 14. The specific empirical equation for this relation has been established as $K=0.25755678929 * P_{t}-1.38762128$ with coefficient of determination of 0.937837 .

\subsubsection{Relation between Salinity and Average Transverse Resis-} tivity. The decrease of resistivity values is considered as an indication of increase of either clay content and/or water salinity (both two factors led to poor water quality). In the present work, the relation between the recorded resistivity values from electrical soundings and the corresponding salinity (TDS) values beside wells are plotted in Figure 15. This plot shows the confidence of TDS with $P_{t}$ as TDS = $-132.558449 * P_{t}+6867.81438$ with coefficient of determination of 0.840022 . The slope of line is negative which indicates the decrease in salinity with an increase in the resistivity. It should be mentioned here that the aquifer resistivity of water is not only a function of salinity but also of clay content besides the packing and grain size. Therefore, the above established empirical equations have been utilized in predicting the hydraulic parameters and salinity in all vertical electrical sounding sites in the study area (Table 3 ), which are used as preliminary information for drilling water wells and further management of groundwater supply of the area.

\section{Priority of Water Well Drilling}

In order to make the aforementioned results (Table 3 ) more illustrative and useful for decision makers, a priority map has been presented. The generation of this map depends on the mutual effect of TDS, thickness, transmissivity, and hydraulic conductivity through the saturated layer in the study area besides the depth of water. The collective effects of the saturated layer have been presented to show priority zones in the study region. The saturated layer is characterized by approximately uniform thickness so their weight factor is $10 \%$. The TDS, depth to water, transmissivity, and hydraulic conductivity play a significant role in groundwater utilization. Consequently, their weight factors are 30\%, 20\%, $20 \%$, and $20 \%$, respectively. These factors are essential for the construction of the priority map. The above parameters have been classified into four categories (Table 4).

According to the priority map (Figure 16), it could be concluded that the promising area for drilling water wells is located at the western portion. The priority of groundwater quality and potentiality decrease towards the eastern portion of the concerned area.

\section{Conclusions}

In the deltas of Wadi Badaa and Ghweiba, the Quaternary aquifer forms the major promising aquifer having generally fresh to brackish water. It is built up of sand and gravel with clay and limestone intercalations. This succession overlies directly the Pliocene-Miocene deposits. The groundwater exists under free water table condition at a depth that varies from $39.9 \mathrm{~m}$ in the northwest to $9.4 \mathrm{~m}$ in the east below ground surface. The values of the transmissivity of the Quaternary aquifer range from $318.528 \mathrm{~m}^{2} /$ day to $990.25 \mathrm{~m}^{2} /$ day, and the hydraulic conductivity varies from $3.961 \mathrm{~m} /$ day to $10 \mathrm{~m} /$ day. The groundwater belongs to the slightly fresh to brackish water class, where the TDS ranges between $560 \mathrm{mg} / \mathrm{l}$ and $4670 \mathrm{mg} / \mathrm{l}$. The results of geoelectrical soundings conducted in the close vicinity of the water wells are used for establishing empirical relationships between the hydraulic and geoelectric parameters. The transmissivity is linearly related to the transverse resistance and hydraulic conductivity is also linearly related with the average transverse resistivity, while the salinity is found to be inversely related to resistivity. These relations had been utilized in predicting the hydraulic parameters and salinity in all vertical electrical sounding sites, and a priority of drilling water wells has been presented in the study area. It can be concluded from this study that the geoelectrical sounding method can be successfully used not only for exploration of groundwater resources but also for estimating the hydraulic parameters of the aquifer. It can substantially reduce the amount of test drilling required by allowing a more intelligent selection of the well sites.

\section{Acknowledgments}

The authors are thankful to the Department of Geophysics, Desert Research Center. Facilities provided by Hydrology Department members are also acknowledged. 


\section{References}

[1] R. F. Misak, "Preliminary geologic report, Ras Gharib area," Desert Research InstituteInternal Report 344, Desert Research Institute, 1986.

[2] Continental Oil Company (CONOCO), Stratigraphic Lexicon and Explanatory Notes to the Geologic map of Egypt 1 : 500000. Edited by Maurice Hermina, Eberhard and franz K. list, 1987.

[3] A. Shata, "Some remarks on the distribution of the Carboniferous Formations in Egypt," Bulletin de l'Institut du Désert d'Egypte, vol. 5, no. 1, pp. 241-247, 1955.

[4] A. B. Kostandy, "Facies maps for the study of the Paleozoic and Mesozoic sedimentary basins of the Egyptian region," in Proceedings of the 1st Arab Petroleum Congress, pp. 54-62, Cairo, Egypt, 1959.

[5] R. Said, The Geology of Egypt, A. A. Balkema, Rotterdam, The Netherlands, 1962.

[6] R. Said, The Geology of Egypt, A. A. Balkema, Rotterdam, The Netherlands, 1990.

[7] United Nation, Structure plan for Suez Governorate, Draft final report, V.II, groundwater resources investigations, Norconsult A.S. and MECO, 1979.

[8] Cement Suez Company, Groundwater hydrology of wadi Badaa quantitative analysis, development and plan of operation for the supply of water requirements to the Suez Cement Company, Internal Report, 1981.

[9] Arabian Geophysics, Drilling and well logging for the productive wells to for the Suez Cement Company, Internal Report, 1987.

[10] A. S. Mostafa, Geophysical studies on the area of northwest of Suez, M.S. thesis, Faculty of Science, Ain Shams University, Cairo, Egypt, 1993.

[11] A. M. A. Helal, A. A. El Sayed, S. A. Mousa, and H. El-Meliegy, "Seismic facies analysis of Mesozoic rocks of the Cairo-Suez District," in Proceedings of the 13th Annual Meeting of the Egyptian Geophysical Socity, pp. 59-80, Cairo, Egypt, March 1995.

[12] T. A. Abd Allatief, G. H. Galal, and A. M. A. Youssef, "Structural and lithological impacts on the groundwater occurrences along wadi El Naqra-wadi Badaa area, (a case study)," in Proceedings of the 15th Annual Meeting of the Egyptian Geophysical Socity, pp. 107-124, Egyptian Geophysical Society, March 1997.

[13] A. M. Aboul Ela, "Seismic response analysis of the foundation rocks of El-Ain Ei-Sukhana area Gulf of Suez Egypt as determined from seismic refraction technique," Geological Survey of Egypt, vol. 24, pp. 555-565, 2001.

[14] M. El Houseiny, Geophysical studies on the water bearing formations in Ain El-Sukhana area, M.S. thesis, Faculty of Science, Cairo University, Cairo, Egypt, 2002.

[15] I. M. Nasr, "Geophysical exploration for groundwater aquifers in Wadi Ghawaiba area, West Gulf of Suez," Journal of Faculty of Educational, no. 29, pp. 131-145, 2004.

[16] H. A. Desouki, M. A. Gomaa, M. A. Sadek, and H. A. Ezz El -Deen, "Hydrochemical and isotopic evaluation of groundwater quality, El Ain El-Sukhna and Wadi Araba localities, aquifers, Egypt," Mansoura Journal of Geology and Geophysics, vol. 33, no. 1, pp. 32-64, 2006.

[17] G. M. Duffield, AQTESOLV For Windows Version 4 User's Guide, HydroSOLVE, Reston, Va, USA, 2006.

[18] H. H. Cooper and C. E. Jacob, "A generalized graphical method for evaluating formation constants and summarizing well field history," Transactions, American Geophysical Union, vol. 27, pp. 526-534, 1946.

[19] I. I. Chebotarev, "Metamorphism of natural waters in the crust of weathering-1," Geochimica et Cosmochimica Acta, vol. 8, no. 1-2, pp. 22-32, 1955.

[20] I. I. Chebotarev, "Metamorphism of natural waters in the crust of weathering-2," Geochimica et Cosmochimica Acta, vol. 8, no. 3, pp. 137-170, 1955.

[21] I. I. Chebotarev, "Metamorphism of natural waters in the crust of weathering-3," Geochimica et Cosmochimica Acta, vol. 8, no. 4, pp. 198-212, 1955.

[22] B. P.A. Van Der Velpen, Resist, a computer program for the interpretation of resistivity sounding curve, M.S. thesis, ITC, Delft, The Netherlands, 1988.

[23] W. E. Kelly, "Geoelectric sounding for estimating aquifer hydraulic conductivity," Ground Water, vol. 15, no. 6, pp. 420425, 1977.

[24] P. D. C. Mbonu, J. O. Ebeniro, C. O. Ofoegbu, and A. S. Ekine, "Geoelectric sounding for the determination of aquifer characteristics in parts of the Umuahia area of Nigeria," Geophysics, vol. 56, no. 2, pp. 284-291, 1991.

[25] R. K. Frohlich and W. E. Kelly, "The relation between hydraulic transmissivity and transverse resistance in a complicated aquifer of glacial outwash deposits," Journal of Hydrology, vol. 79, no. 3-4, pp. 215-229, 1985. 

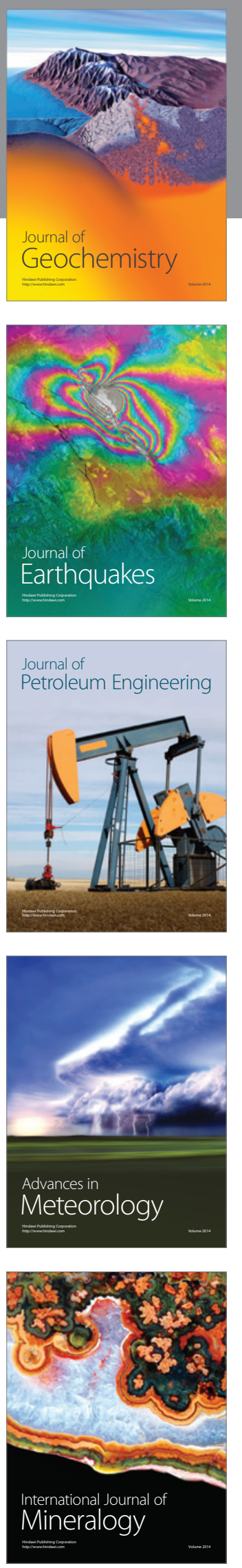
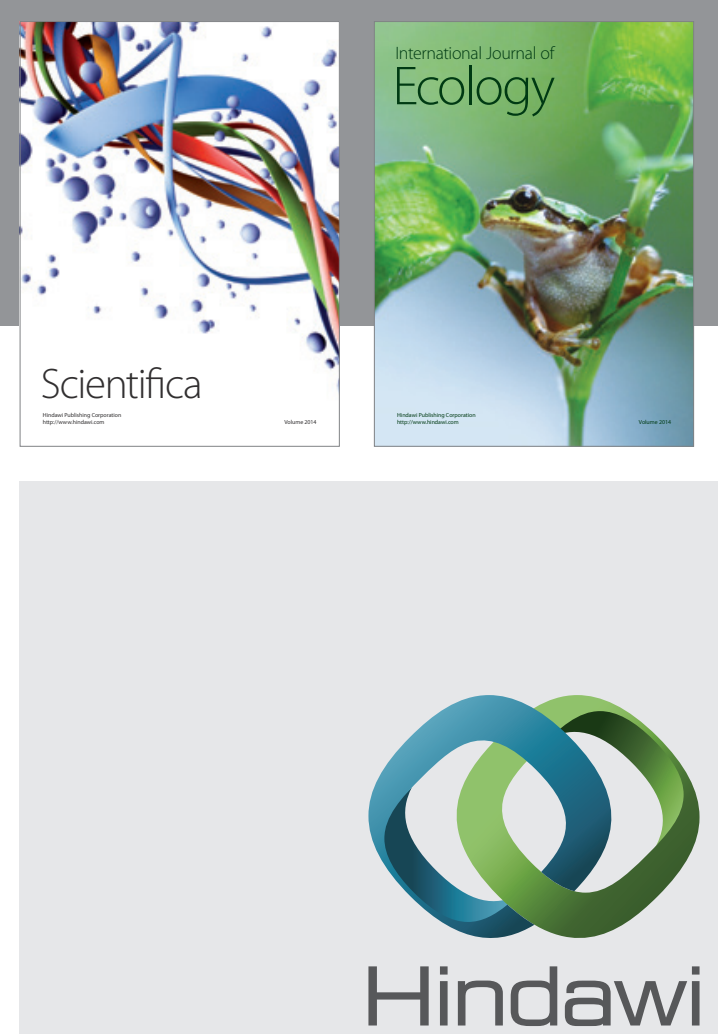

Submit your manuscripts at http://www.hindawi.com
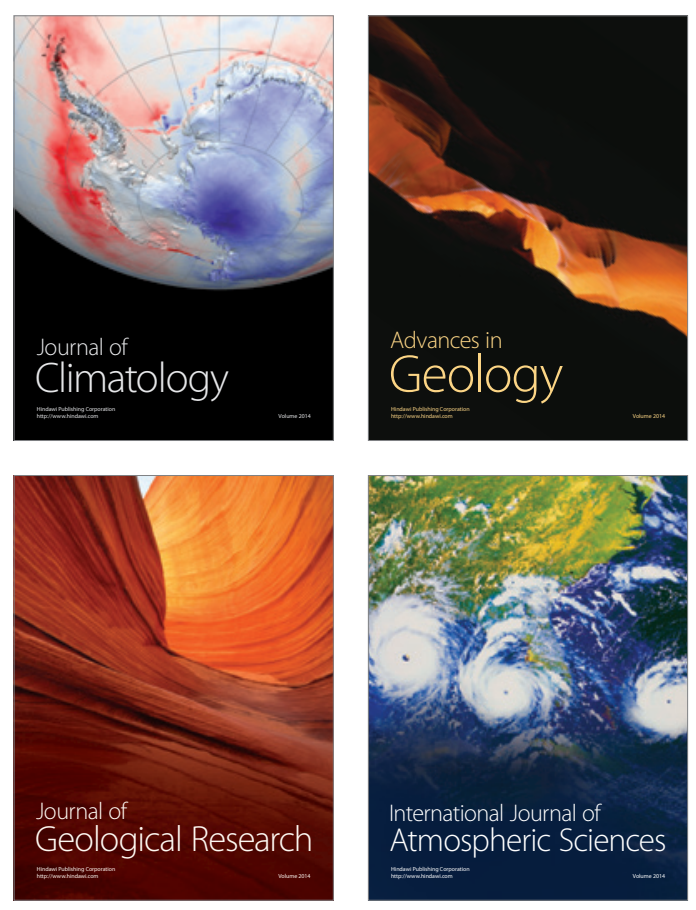
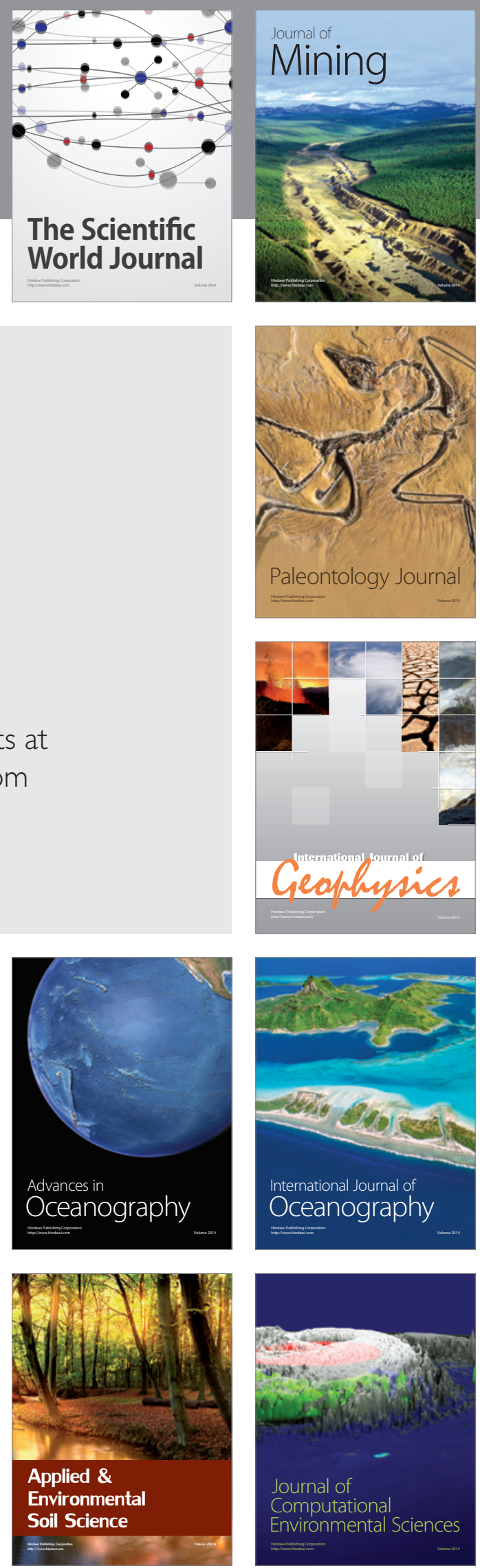